\title{
Ontogenetic Migration of Juvenile Grunts (Haemulon) across a Coral Reef Seascape: Pathways and Potential Mechanisms
}

\author{
Richard S. Appeldoorn ${ }^{*}{ }^{\dagger}$ and Björn L. K. Bouwmeester ${ }^{\ddagger}$
}

check for updates

Citation: Appeldoorn, R.S.;

Bouwmeester, B.L.K. Ontogenetic Migration of Juvenile Grunts (Haemulon) across a Coral Reef Seascape: Pathways and Potential Mechanisms. Diversity 2022, 14, 168. https://doi.org/10.3390/d14030168

Academic Editors: Michael Wink, Charlotte Berkström and Simon Pittman

Received: 25 January 2022

Accepted: 17 February 2022

Published: 26 February 2022

Publisher's Note: MDPI stays neutral with regard to jurisdictional claims in published maps and institutional affiliations.

Copyright: (C) 2022 by the authors. Licensee MDPI, Basel, Switzerland. This article is an open access article distributed under the terms and conditions of the Creative Commons Attribution (CC BY) license (https:// creativecommons.org/licenses/by/ $4.0 /)$.
Department of Marine Sciences, University of Puerto Rico, Mayagüez 00681, Puerto Rico; bjornhilo@gmail.com

* Correspondence: richard.appeldoorn@upr.edu

+ Current address: HC-01 Box 5175, Lajas 00667, Puerto Rico.

$\ddagger$ Current address: 1760 SW 15th Street, Miami, FL 33145, USA.

\begin{abstract}
Many coral reef fishes undergo ontogenetic migrations from inshore nurseries to offshore reefs. Quantifying cross-habitat connectivity is important for understanding reef fish spatio-temporal dynamics, essential habitat and spatial planning. Past studies show connectivity is mediated by distance and habitat arrangement. Few studies have documented the pathways linking juveniles and adults, nor suggested underlying orientation/navigation processes important for a more generalized understanding of ontogenetic habitat use. Ontogenetic movements of juvenile grunts, primarily Haemulon flavolineatum, in Puerto Rico were studied using mark-recapture. Small juveniles were tagged at a back-reef site designed to determine their potential movement through a series of sizespecific daytime resting schools and posing a choice of direction in migration. Larger juveniles were tagged at mid-shelf reefs to capture off-reef migration to adult locations, including a proposed marine reserve. Small juveniles moved toward more exposed areas, accomplished by progressively shifting locations through existing resting schools. Movement was size-related and alongshore, but direction was primarily parallel to the coast, leading fish away from adjacent areas more directly offshore. Direction may have resulted from the potential mechanism of fish transfer between resting schools rather than by orientation cues. Larger juveniles were tracked from back-reef to fore-reef sites, but no fish were recaptured off-reef. Slower growth than predicted may have contributed to the perceived lack of movement. Localized behavior and habitat distribution appear important in determining the initial pathways of ontogenetic migration, and these may fix later directional movements to unexpected areas.
\end{abstract}

Keywords: ontogenetic migration; nursery areas; tagging; coral reef fish; grunts; Haemulon flavolineatum

\section{Introduction}

Many coral reef fishes show characteristic habitat shifts during ontogeny [1-6]. Such ontogenetic migrations are thought to minimize the ratio of mortality over growth [7], which has been supported empirically [3,8-10]. Ontogentic migrations are well-defined in grunts (Haemulidae) and evidenced by the shift to larger size distributions with progressive offshore locations $[1,2,5,6,11]$.

During ontogeny, juvenile grunts undergo a series of migrations between habitats (and associated resting schools) $[2,5,6,11,12]$. These migrations are associated with changes in diet and behavior $[2,10,13,14]$ and appear to be strongly correlated with fish length $[10,15]$. There are six eco-behavioral stages of development reported for Haemulon flavolineatum and H. plumierii $[2,16]$. These stages begin with newly settled fish and proceed through to adults. Newly settled fish start life by settling at $1-1.5 \mathrm{~cm}$ TL. At this point, they are considered Stage 0 juveniles and settle opportunistically on small, isolated structures within seagrass beds and backreef areas [17] while continuing to feed on plankton during the day. Stage 0 fish begin nightly off-site migrations, but do not feed. As juveniles (Stage 1 and 2), they aggregate on patch reefs or in mangrove stands and size-segregate into schools [18]. At 
$3.0 \mathrm{~cm}$ TL (Stage 1), individuals form daytime resting schools on structures within seagrass or mangroves near the reef. Individuals at this stage are transitional in their feeding ecology, and smaller individuals may continue to feed on plankton during the day. From 5.5 to $12 \mathrm{~cm}$ TL (Stage 2), H. flavolineatum continue to form daytime resting schools, but migrate at twilight over specific pathways to feed nocturnally in areas within seagrass and other soft-bottom habitats [19-22]. Return migrations occur over the same pathways during morning twilight. Individuals transition forward on the reef where schools are found in deeper water and along the reef edge [17]. At 12.0 to $15.0 \mathrm{~cm} \mathrm{TL}$ (sub-adult), H. flavolineatum continue to school during the daytime and migrate to feeding grounds at night. Although they migrate and school, they begin to roam and display more adult-like behavior. At $15 \mathrm{~cm}$ TL (adult), $H$. flavolineatum mature and migrate offshore [2,11].

Inference from school positions and mean size give a general indication of the transitional timing and the general areas/habitats involved in ontogenetic migrations, but do not indicate the pathways. Documenting pathways may help identify potential underlying factors associated with orientation and direction, which in turn could point to general rules governing fish movements [16]. Understanding these pathways is also critical for protecting essential fish habitats and areas acting as a nursery or source areas for adult populations [23], with MPA design being an obvious case. Burke et al. [24] and Jaxion-Harm et al. [25] calculated potential priority nursery areas based on densities and abundances of small-juveniles, and Mateo et al. [26] used stable isotopes in otoliths to estimate the contribution of sea grass versus mangroves nurseries to the population a year later. These studies suggested that not all areas occupied by early juveniles contribute equally to later age groups. Yet, neither approach considered the potential pathway of ontogenetic migration, so direct spatial connections between key nursery habitats to those occupied by later stages remain unknown. Mumby [27] and Martin et al. [28] assumed straight-line pathways when attempting to quantify at what distances there was a disconnect between mangrove nursery areas and potential adult habitats on coral reefs.

Pathways that are bounded by land are simple to understand (e.g., embayments with narrow openings to open reef environments [5,12]); however, it is more difficult to determine pathways, orientation cues, and factors affecting migration in an open coastal environment consisting of mangrove and seagrass beds sheltered by fringing reefs. Little is known of the actual pathways taken by juveniles to adult habitat. Appeldoorn et al. [11], commenting on the lack of such studies for tropical marine fishes, emphasized the need to understand the linkage between habitats and developmental stages. Dorenbosch et al. [29] compared adult populations on reefs $>9 \mathrm{~km}$ distant from inshore mangrove and seagrass habitats and found most species (including grunts) to have reduced densities on reefs located directly offshore over open habitats compared to those reefs connected along shore. They concluded that migration along the coast would explain these differences. Appeldoorn et al. [16] reported finding one white grunt (H. plumierii) at an outer emergent reef that had been tagged 3 years prior $(\sim 8 \mathrm{~cm} \mathrm{FL})$ directly inshore, but given there was an extensive linear reef between these two locations, a direct pathway could not be determined.

In the Caribbean, grunts are ubiquitous and abundant, representative of medium-sized reef fishes, and have substantial importance commercially [30,31] and ecologically $[32,33]$. This study aims to ascertain the direction taken by juvenile grunts, mainly H. flavolineatum, and the potential cues used during ontogenetic migration through a mark and recapture program. The study was designed to investigate these movements at two different scales. A small-scale study was designed to track movement among schools within a single reef site. At a larger scale, the movement of individuals targeted the migration pathways and cues used by subadults thought to make larger transitions to off-reef locations. Tagging and subsequent recovery locations were specifically selected to reveal potential environmental cues related to choices of migratory pathways. Specifically, sites were located such that potential movement would most likely be constrained to different pathways determined by bathymetry or by movement across open water toward upstream habitat cues. In the smallscale study, it was hypothesized that movement would be constrained by bathymetry and 
that fish would move along a pathway leading to adjacent offshore reefs to the southwest. The large-scale study targeted a potential choice of offshore pathways: directly up-current or directly toward the nearest reef. Choice of direction could signal which cues fish use to orient movements (e.g., olfactory, acoustic cues or need for shelter). While the goal was to elucidate general processes, the tagging sites were also oriented relative to potential movement toward a proposed marine reserve [34], so results could be applied to identifying source areas for the reserve.

\section{Materials and Methods}

\subsection{Study Sites}

The study was conducted at La Parguera (Figure 1) located in southwest Puerto Rico $\left(17.97159^{\circ} \mathrm{N}, 67.04517^{\circ} \mathrm{W}\right)$. The embayment at La Parguera consists of three shelf reef systems (inner, middle, and outer) that parallel the coast [35]. These reefs are not subject to freshwater input, except during rain. The average depth of the shelf is between $18-20 \mathrm{~m}$, with the inner shelf averaging $6 \mathrm{~m}$ [36].
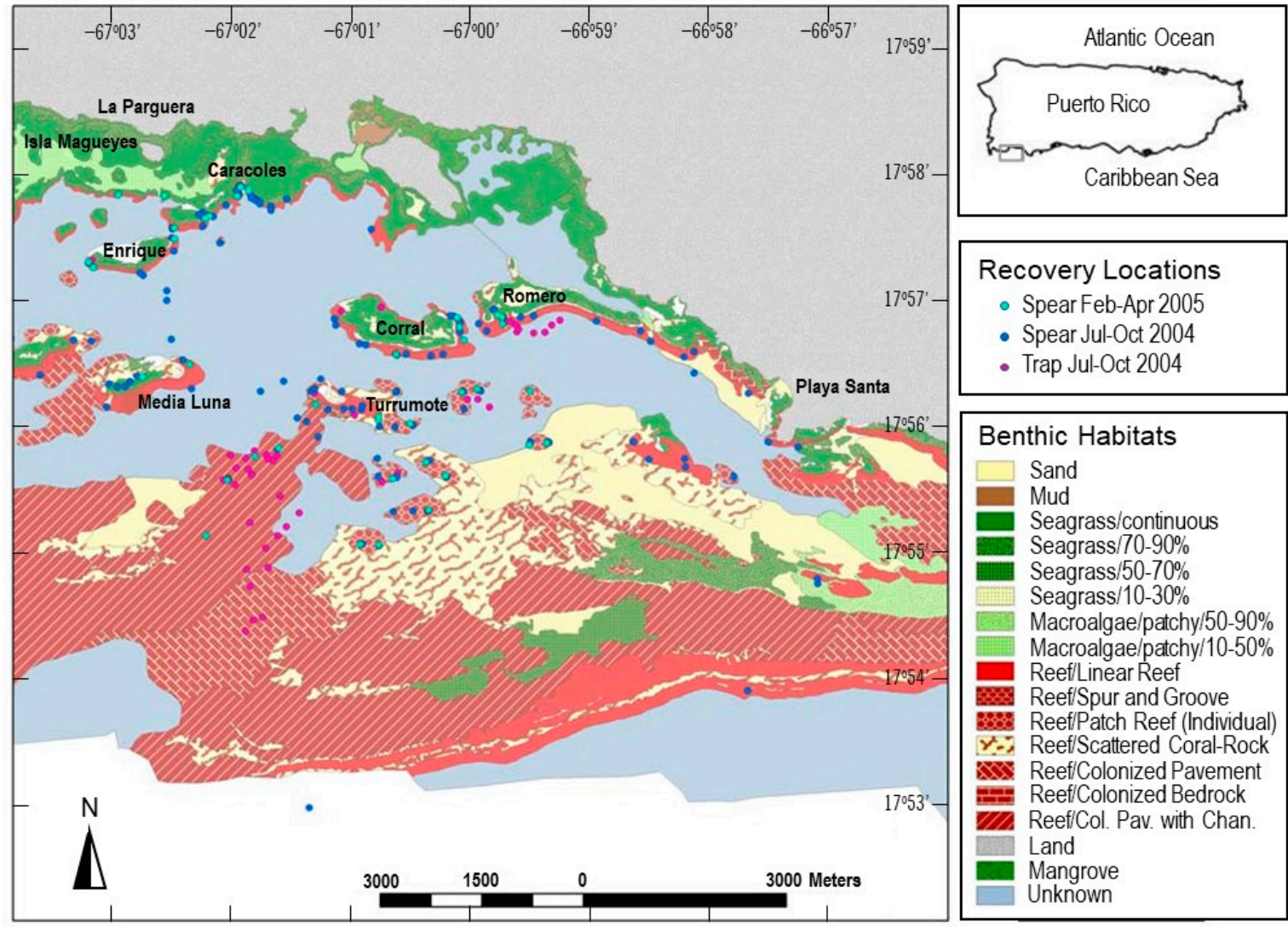

Figure 1. Habitat map of the study area off La Parguera, Puerto Rico (from Kendall et al. [37]). Circles indicate locations for attempted recapture by spearing and trapping of Haemulon flavolineatum.

Tagging was conducted at three inner shelf reefs: Caracoles, Corral, and Romero (Figures 1 and 2). Caracoles proper is covered by mangroves, protecting a shallow lagoon with seagrass. The reef is linear and runs on a northeast axis curving to the east at the northern tip. Depths along the fore reef approach $10 \mathrm{~m}$ at the reef slope. The lagoonal area behind the reef is less than $2 \mathrm{~m}$. The reef is approximately $850 \mathrm{~m}$ long and has an adjoining submerged reef area called Majimo (Figure 3), which is where tagging and initial recaptures were conducted. Majimo is composed of two patch reefs surrounded by seagrass and patches of gorgonians. A $2 \mathrm{~m}$ deep seagrass channel runs between the patch reefs, and a $4 \mathrm{~m}$ deep channel that grades from seagrass around the reef halo into sand and rubble near the reef slope further separates Majimo from Caracoles. Twelve day-time resting 
schools of juvenile $H$. flavolineatum were located at the Caracoles site and grade from small mean sizes to larger sizes toward the reef slope (Figure 3, Table 1). Schools are found within crevices and depressions within the coral structure, and also among the branches of Acropora cervicornis and Millipora complanata.
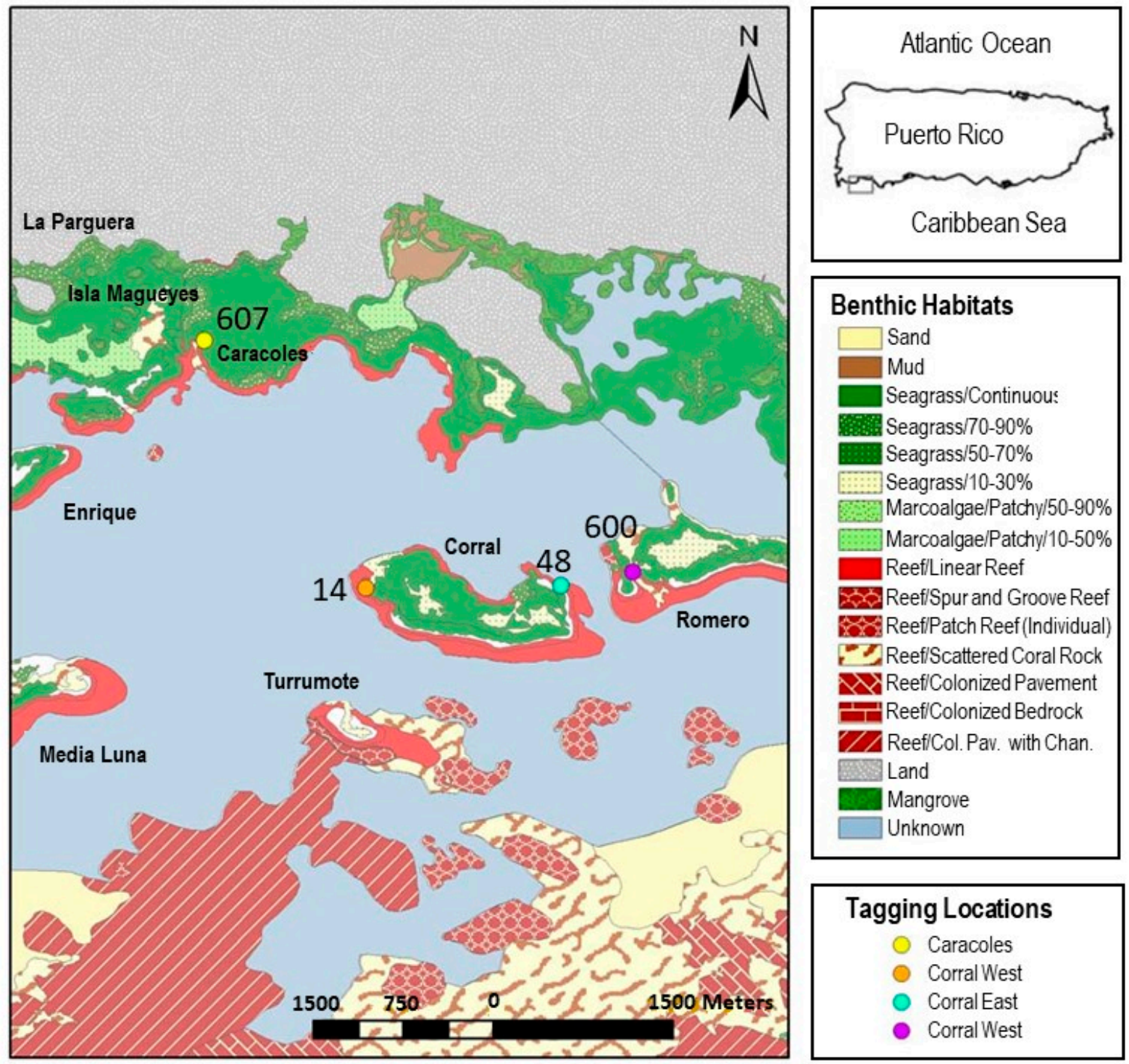

Figure 2. La Parguera, Puerto Rico showing benthic habitats (from Kendall et al. [37]) and the tagging locations of Haemulon flavolineatum located on the three reefs used in the study. Numbers indicate the number of fish tagged at each site for the study of large-scale juvenile movement.

This site was chosen because it appeared to offer two different potential pathways to locations further offshore (Figure 3). One is to the southwest and perpendicular to prevailing waves and currents. This path would presumably direct older fish toward sites further along Caracoles and then to the reefs further offshore, Enrique and Media Luna (Figures 1 and 2), the latter being where Appeldoorn et al. [16] reported recapturing the individual H. plumierii. The other pathway runs east and more into prevailing waves and current. The path extends along a continuous reef line, potentially toward a point directly inshore of Corral and then Turrumote, two other reefs further offshore (Figures 1 and 2). These two reefs formed part of the inshore-offshore transect studied by Aguilar-Perera and Appeldoorn [6,38]. 


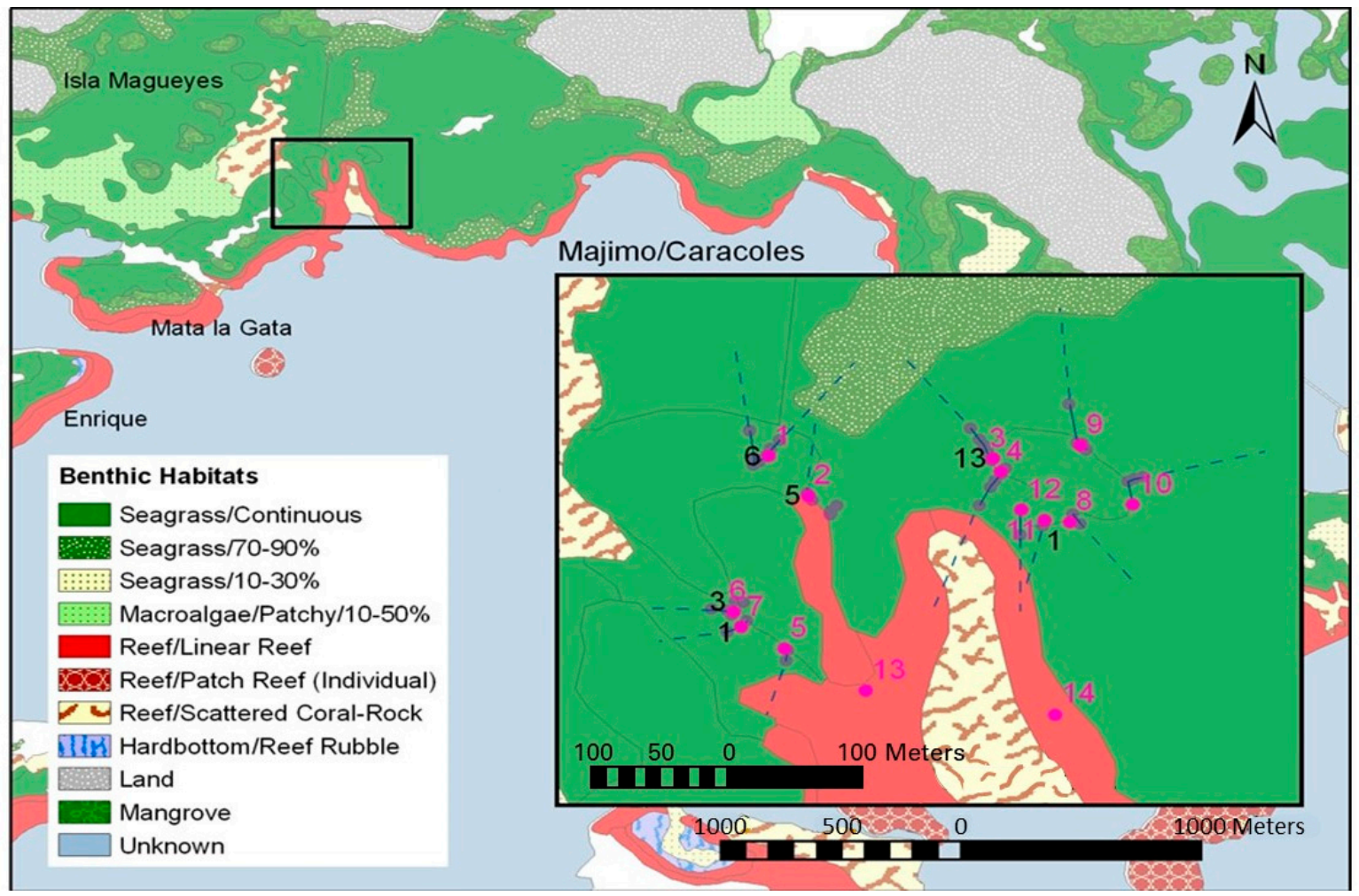

Figure 3. Location of juvenile grunt resting schools monitored for tags at Majimo/Caracoles reef in La Parguera, Puerto Rico. Red numbers and dots are the schools (See Table 1); black numbers are the number of recaptured individuals at each location from a total of 168 tagged at Site 1 . Solid blue lines are the confirmed feeding routes, while dashed lines are the extension of those routes. Benthic habitats shown are from Kendall et al. [37].

Table 1. Descriptive statistics for fork length $(\mathrm{cm})$ by location of all juvenile Haemulon spp. observed in resting schools found in the Majimo/Caracoles area of the initial mark-recapture study. Samples are the number of sampling events. $\mathrm{N}$ is the number of fish caught and measured.

\begin{tabular}{ccccccc}
\hline School & Samples & $\mathbf{N}$ & Minimum & Maximum & Average & Median \\
\hline 1 & 3 & 774 & 4.7 & 12.0 & 6.93 & 6.6 \\
2 & 3 & 97 & 7.4 & 27.8 & 13.02 & 12.1 \\
3 & 3 & 1121 & 5.0 & 13.9 & 7.84 & 7.6 \\
4 & 2 & 1315 & 4.6 & 12.2 & 7.66 & 7.2 \\
5 & 3 & 584 & 4.5 & 13.1 & 7.98 & 7.5 \\
6 & 3 & 1713 & 5.0 & 16.0 & 7.47 & 7.2 \\
7 & 3 & 2203 & 5.1 & 14.2 & 8.35 & 8.5 \\
8 & 3 & 564 & 5.5 & 16.1 & 10.23 & 10.5 \\
9 & 3 & 740 & 4.4 & 13.6 & 8.10 & 8.2 \\
10 & 3 & 948 & 5.1 & 28.5 & 8.00 & 7.0 \\
11 & 4 & 231 & 5.8 & 16.3 & 9.88 & 9.9 \\
12 & 3 & 614 & 4.9 & 14 & 8.01 & 7,8 \\
13 & 1 & 9 & 12.8 & 16.4 & 13.91 & 13.1 \\
14 & 1 & 23 & 11.5 & 15.2 & 13.74 & 13.8 \\
\hline
\end{tabular}

The reef platform at Corral is $2 \mathrm{~km}$ long and $630 \mathrm{~m}$ wide (Figure 2). The fore reef is $\mathrm{u}$-shaped and runs east to west. There is a coral rampart on the seaward side with a few mangrove trees established. On the east side is a deep channel $(20 \mathrm{~m})$ separating the reef from Romero. This side has no mangroves, and a small coral rampart is formed. A shallow reef terrace, composed of small outcroppings and crevices of coral, extends into a gorgonian plain that drops to $20 \mathrm{~m}$. At the northeast corner of the reef (near the tagging 
site), water flows over the reef crest. The resting school targeted for tagging sits on a shallow patch of $M$. complanata that is bordered on the lagoonal side by seagrass at $0.5 \mathrm{~m}$. The lagoon is less than $2 \mathrm{~m}$ deep and is composed of thick beds of Thalassia testudinum and smaller patches of Syringodium filiforme; interspersed are alga hummocks. The lagoon side of Corral gradually drops from $2 \mathrm{~m}$ down to $20 \mathrm{~m}$ toward the mainland. On the western extension of Corral, there is a large emergent patch reef (another tagging site) separated from the main reef by a shallow channel. Interspersed among the various coral heads was a large school of juvenile French grunts. They occupied sheltered areas formed by colonies of A. cervicornis or that occur around the bases of Siderastrea siderea. Romero is an L-shaped fringing reef covered with mangroves and at its far eastern end is connected to the mainland by a narrow lagoonal channel (Figures 1 and 2). The reef is $3.3 \mathrm{~km}$ long with a relatively shallow $(5 \mathrm{~m})$ short $(50 \mathrm{~m})$ terrace composed of gorgonians and reef pavement. The lagoon side of Romero is composed of shallow seagrass beds. At the seaward edge, the slope drops quickly to $20 \mathrm{~m}$. A channel separates the western end of the emergent reef from the main reef. The channel is $6 \mathrm{~m}$ at the deepest end and is lined with sand. It is deeper at the seaward mouth and shallows less than $2 \mathrm{~m}$ at the lagoon side. At the edges, the channel is lined with boulder corals. An extremely large school of juvenile H. flavolineatum (targeted for tagging) was located midway on the east side of the channel, residing in large clumps of A. cervicornis.

\subsection{Small-Scale Study}

The experiment on small juvenile movement occurred at Majimo (Figure 3), where several schools in close proximity were located. The exact position of each school was determined using a Garmin ${ }^{\mathrm{TM}}$ (Garmin, Schaffhausen, Switzerland) GPS with differential correction, and the approximate size, range, and quantities at each school were recorded using visual census. For each school, the twilight feeding migrations were observed, and pathways were marked with floats. One school (Site 1, Figure 3 and Table 1) was selected for tagging based on the desired median size and abundance of fish, potential sites for recapture, as well as the relative position of the site to factors thought to affect ontogenetic habitat shifts, such as the amount, type, depth, and location of surrounding habitats. In addition, initial observations indicated a general increase in the mean length of fish in resting schools more seaward of Site 1, indicating the potential of fish leaving Site 1 to move toward these other schools. Fish from Site 1 were trapped four times using an adaptation of Ogden and Ehrlich's [18] net-and-trap method over a 1 month period (22 August 200324 September 2003). The net and trap were placed across the migration pathway in such a manner that the nets guided returning fish toward the trap mouth. The trap was monitored at dawn, and when the fish were corralled into the trap, a gate was closed. The trap was brought to the surface and served as a holding pen.

Fish were removed from the trap in small batches and placed in buckets of fresh seawater for tagging, measuring fork length (FL) and total length, and checking for tags prior to tagging. Untagged fish were then tagged with Northwest Marine Technology's (NMT) (Anacortes, WA, USA) decimal coded wire tags (DCWT). Details of tagging procedures and assessment of impacts on survival and growth are given by Bouwmeester [39]. Briefly, fish were tagged in the nape [40-42] using a NMT Handheld Multishot Injector. Fish were individually hand-held while inserting the tag. Retention was checked using a NMT handheld tag detector. Reference tags were saved in a silicon strip. Saving a reference tag for each fish ensured that each individual could be identified should there be any problems reading the tag upon recapture. Tagged fish were placed in a holding pen and subsequently released at the schooling location. Fish were allowed a 1 month period to recover and grow before trapping for recaptures commenced.

Sampling for recaptures ran from 22 October 2003 to 10 March 2004 and occurred at the 12 resting school locations using the same trapping procedure, and at two additional resting schools (13 and 14) (Figure 3). Fish at the latter locations consisted of larger individuals showing subadult behavior. At these sites, the change in behavior required that spearing 
be used for recapture sampling. Each of the initial 12 resting schools was targeted multiple times over the six-month recapture period, with sampling intervals averaging 36 days (range 26-44) (Tables 1 and 2). Captured fish were measured (FL and TL) and checked for tag retention. Tagged fish were retained and brought to the laboratory for tag removal.

Table 2. Descriptive statistics for fork length $(\mathrm{cm})$ by species of all juvenile Haemulon spp. observed in resting schools found in the Majimo/Caracoles area of the initial mark-recapture study. Includes samples for both tagging and recapture. $\mathrm{N}$ is the number of fish caught and measured.

\begin{tabular}{ccccccc}
\hline Species & $\mathbf{N}$ & $\mathbf{\%}$ & Minimum & Maximum & Average & Median \\
\hline H. flavolineatum & 8820 & 82.330 & 4.4 & 16.4 & 8.07 & 7.8 \\
H. plumierii & 1352 & 12.620 & 5 & 28.5 & 8.24 & 7.8 \\
H. aurolineatum & 407 & 3.799 & 5.6 & 12.3 & 7.62 & 7.3 \\
H. carbonarium & 55 & 0.513 & 5.5 & 14.8 & 8.72 & 8.4 \\
H. chrysargreum & 55 & 0.513 & 6.2 & 15.4 & 9.25 & 8.5 \\
H. sciurus & 22 & 0.205 & 9.5 & 27.8 & 16.67 & 15.6 \\
H. macrostomum & 1 & 0.009 & & & 9.90 & \\
H. parra & 1 & 0.009 & & & 16.50 & \\
ALL $=$ & 10,712 & & 4.4 & 28.5 & 8.11 & 7.8 \\
\hline
\end{tabular}

At the laboratory, tagged fish were measured (FL and TL) and weighed. Tags were cut out and placed in a labeled beaker. Flesh was dissolved from the tags using a $4 \%$ sodium hydroxide solution (Drāno ${ }^{\mathrm{TM}}$, SC Johnson, Racine, WI, USA), rinsed in water, and read under a dissecting microscope. Tags were manipulated with a magnetic tag pencil.

\subsection{Large-Scale Study}

Four locations were selected to study movements of larger transitional individuals: Caracoles, Corral East, Corral West, and Romero West (Figures 2 and 4). These locations were selected due to the abundance of individuals, their position relative to potential recapture sites that may help deduce the cues used by migrating fish, and their position relative to a proposed marine reserve located further offshore at Turromote (Figure 2) [34]. Corral and Romero are located directly inshore of Turromote, while Caracoles is down current. Movement from the Caracoles site could also provide an extension to any dispersal observed from the study of small juveniles. Here, the tagging site was the resting school located at site 8 (Table 1, Figure 3).

Tagging with DCWTs followed the procedure above. Greater effort was put into tagging juveniles of at least $10 \mathrm{~cm}$ (FL) at Romero and Caracoles, while fewer fish were tagged at Corral due to the difficulty of capturing fish. The targeted size was designed to get sufficient numbers of tagged individuals (using the net-trap method), while minimizing the time at large because this is near the suspected transition size from juvenile to adult stages in H. flavolineatum [16].

Fish were captured from May 2004 to October 2004. Recovery sampling occurred from July to October 2004, and again from February to April 2005. During the first period, 109 sites were targeted using spearing, and 39 sites were targeted using fish traps. The 2005 follow-up period targeted 39 sites using spearing (Figure 1). Selection of recovery sampling sites (Figure 1) was based on the NOAA benthic habitat map [37] cross-referenced with depths for likely locations that may contain adult fish. For spearing, dives were planned for 30 to $45 \mathrm{~min}$ at each site and two divers speared fish with Hawaiian slings. Shallower areas were explored by snorkeling. When sites were in close proximity, more than one site could be sampled per trip. At each site, divers would approach a school of grunts and attempt to spear as many as possible, including following individuals as they dispersed. As spearing tended to remove most of the fish at a given site, sites were not repeat-sampled. At trap sites, fish were targeted using unbaited Antillean arrowhead traps soaked for 3-5 days. After hauling, traps were moved to a new location. Laboratory methods followed those of small-scale juveniles. 


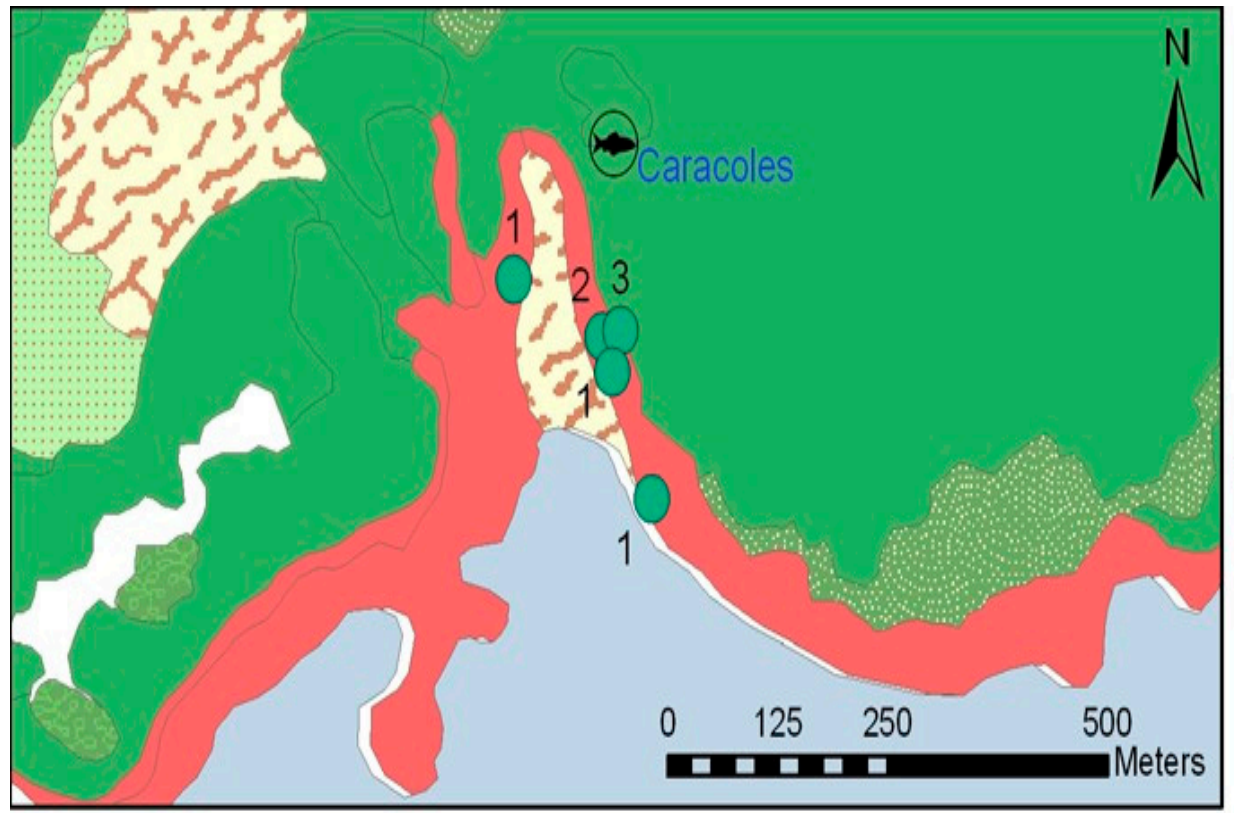

\section{Tagging Location}

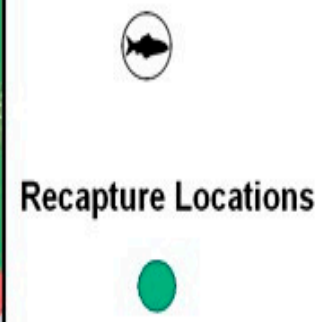

\section{Benthic Habitats}
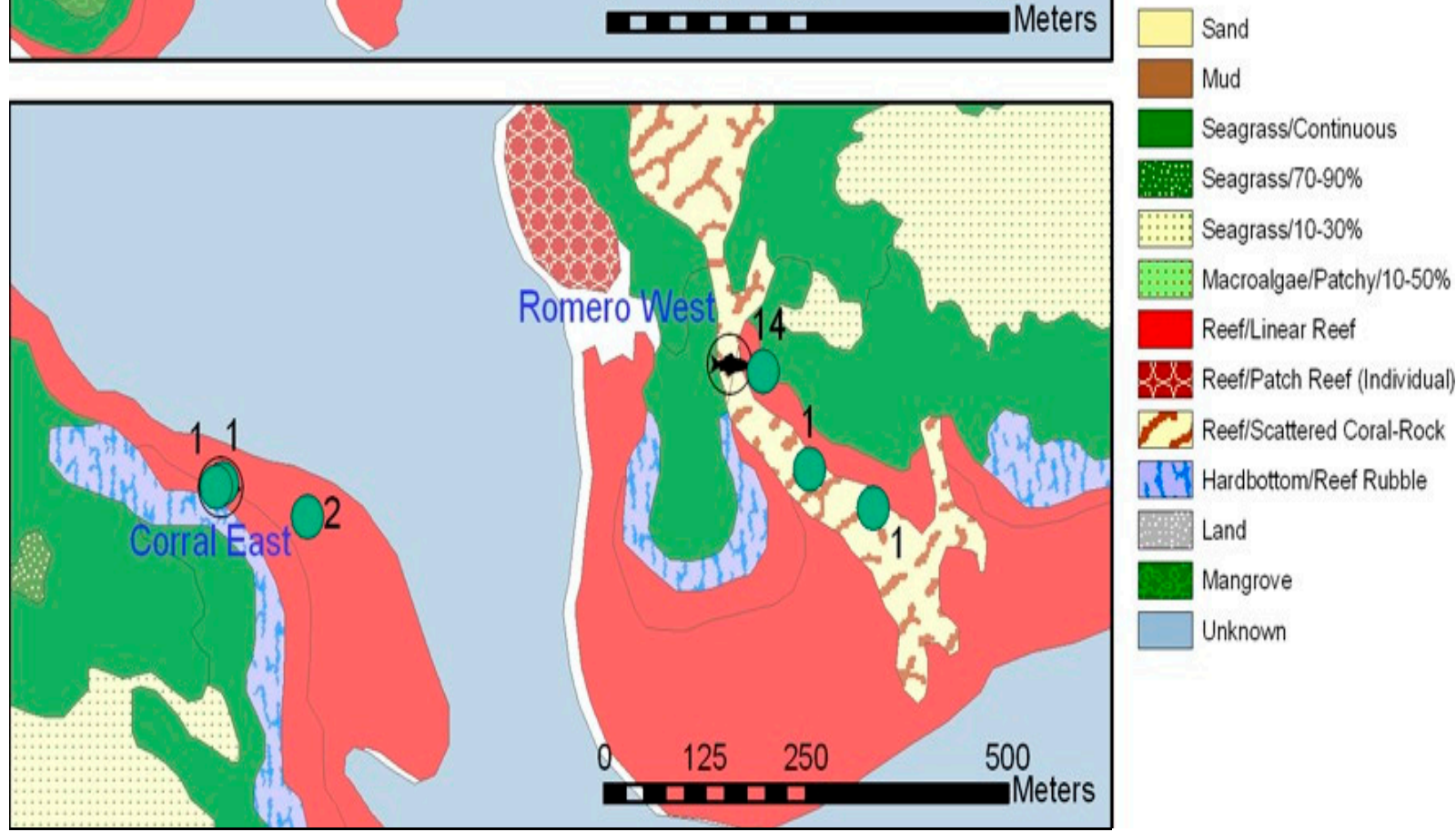

Figure 4. Tagging locations on three reefs with the benthic habitats (from Kendall et al. [37]) for La Parguera, Puerto Rico and the subsequent recovery locations and numbers for large juveniles.

\subsection{Data Analysis}

For small-scale movements, a difference in the mean length (FL) of fish in schools was tested to see if there was a relative increase in the mean length of resting schools seaward of Site 1. For this, the habitat map was used to classify sites as being on-reef (site 2), near reef (sites $4,5,8,11$ ), or seagrass (all other sites). Size structure was tested among the three groups with the expectation that reef sites would contain the largest fish, while seagrass sites would contain the smallest fish. The model was run using a Permutational Multivariate Analysis of Variance (PERMANOVA) as implemented in Primer v.7 with a PERMANOVA add-on [43]. The PERMANOVA was run in univariate mode using Euclidean distances and with a nested design, where habitat was a fixed factor and school was a random factor nested within the habitat. $P$-values were obtained using 9999 permutations. A $p$-value of 0.05 was used to evaluate statistical significance. Because of the large size of the data set, 
the analysis was run separately for the first three time periods each site was visited for recapture sampling.

For small-scale movements, regression analysis was used to test for a relationship between distance moved and the factors of initial FL, growth rate, and days at liberty. The relationship between size and movement was further examined for those fish migrating from School 1 to School 3. This analysis keeps distance and other factors constant and tested whether early migrating fish were of a larger mean initial FL than later migrants. A Jonckheere-Terpstra test was used to compare the initial FLs of three groups of fish based on days at liberty prior to arrival at School 3 against the alternative hypothesis that initial FL increased as days at liberty increased. Due to the existence of ties, the permutation exact test was implemented in R [44] using the DescTool package (ver. 0.99.44) with 5000 permutations. For the analysis, fish were grouped into three periods based on days at liberty; this allowed all fish to be included, thus incorporating maximum variability, while eliminating times represented by a single fish, which could not be utilized in the permutation analysis.

Directionality was tested using a binomial probability that individuals favored seaward migration to the east of the channel (Sites 2, 3, 4, 12, 11, and 8) versus the west side (Sites 6, 7, 5).

For large-scale movements, regression analysis was used to test if distance moved was a function of initial FL over all recaptures and for just those fish that moved. Additionally, the mean initial FL was compared between fish that moved and fish that did not move using a one-tailed t-test with equal variances (confirmed with Levine's test). A fish had to be recaptured at least $50 \mathrm{~m}$ from the tagging site for it to be considered as having moved, similar to Verweij and Nagelkerken [45], who estimated the daily activity radius of $50 \mathrm{~m}$ for H. flavolineatum over a 48-day study.

\section{Results}

\subsection{Small-Scale Juvenile Movement}

One hundred and sixty-eight fish were tagged to study small-scale interschool movements. Eighty percent of tagged fish were Haemulon flavolineatum $(\mathrm{n}=134)$ and $20 \%$ were H. plumierii $(\mathrm{n}=34)$. Over the 4-month period from October 2004 to January 2005, a total of 10,712 fish were sampled for recaptures (Table 2), with $1288 \mathrm{H}$. plumierii $(13 \%)$ and 8648 H. flavolineatum (82\%) with six other species constituting the remaining $5 \%$. Sizes ranged from 4.4 to $28.5 \mathrm{~cm}$ FL. Among the initial 12 schools sampled, no differences were found in mean length among the three habitats, although the relatively large Pseudo-F values ( $>3$ ) suggest the test lacked sufficient power (Table 3). Within each sampling time, all mean lengths among schools were statistically different, except the following: Time 1 and Time 3-Schools 3 and 10 were similar; Time 2-Schools 3, 6, and 9 were similar. Schools 3,9 , and 10 were adjacent and located at the most inshore locations (i.e., shallowest and most distant from the deeper channel) east of the tagging site (Figure 3). School 6 was similarly the most inshore site along the western side. School 1, the site of tagging, consistently had the smallest average length $(6.93 \mathrm{~cm} \mathrm{FL})$, while School 12, the only resting school located on the reef habitat (Figure 3), consistently had the largest average length (13.02 cm FL).

A total of 29 tagged fish were recovered (Table 4): 3 H. plumierii (9\% recapture rate) and $26 \mathrm{H}$. flavolineatum (19\% recapture rate). Of these, 28 could be read (one tag was lost in the recovery process) (Table 4). Of the 28 recovered tags 18 (64.3\%) were from the second tagging session and $6(21.4 \%)$ were from the fourth tagging session at Site 1 . Time at liberty ranged 21-158 days. From those 29 fish, six were recaptured at the tagging site. One was caught after only 21 days at liberty. The other five were caught in a single recapture sample; four were free for 101 days, while the remainder was free for 80 days. 
Table 3. Results of the univariate PERMANOVA on mean fork length of Haemulon resting schools in the Majimo/Caracoles area during the small-scale mark-recapture event. School is nested within the habitat. The analysis was run separately for three different sampling periods. $\mathrm{df}=$ degrees of freedom; $\mathrm{SS}=$ sums of squares; $\mathrm{MS}=$ mean square; $\mathrm{P}($ perm $)$ is the $p$-value derived from the permutations.

\begin{tabular}{ccccccc}
\hline Source & df & SS & MS & Pseudo-F & P(perm) & Unique Permutations \\
\hline Time 1 & & & & & & \\
$\quad$ Habitat & 2 & 1645.5 & 822.74 & 3.331 & 0.099 & 999 \\
School (Habitat) & 10 & 2546.3 & 254.63 & 65.459 & 0.001 & \\
$\quad$ Residual & 1722 & 6697.3 & 3.89 & & & \\
$\quad$ Total & 1734 & 10,889 & & & & 998 \\
Time 2 & & & & & & \\
$\quad$ Habitat & 2 & 716.1 & 358.04 & 3.427 & 0.095 & \\
School (Habitat) & 9 & 1421.1 & 157.9 & 54.074 & 0.001 & 999 \\
$\quad$ Residual & 3471 & 10,135 & 2.92 & & & \\
$\quad$ Total & 3482 & 12,273 & & & & \\
Time 3 & & & & & & \\
$\quad$ Habitat & 2 & 1172.5 & 586.26 & 3.942 & 0.100 & \\
School (Habitat) & 9 & 2505.9 & 278.43 & 123.09 & 0.001 & \\
$\quad$ Residual & 4837 & 10,941 & 2.26 & & & \\
$\quad$ Total & 4848 & 14,620 & & & & \\
\hline
\end{tabular}

Table 4. Recovery data for ontogenetic movement of small, tagged juveniles of Haemulon flavolineatum (Flav) and H. plumierii (Plu) among school groups. The numbers before the dash in the recovery column is the school group (location) and the number after the dash is the visit (time).

\begin{tabular}{ccccccc}
\hline Species & $\begin{array}{c}\text { Date } \\
\text { Tagging }\end{array}$ & $\begin{array}{c}\text { Days at } \\
\text { Liberty }\end{array}$ & $\begin{array}{c}\text { Recovery } \\
\text { Location- } \\
\text { Sample }\end{array}$ & $\begin{array}{c}\text { Initial Fork } \\
\text { Length }(\mathbf{c m})\end{array}$ & $\begin{array}{c}\text { Change in } \\
\text { Fork Length } \\
\text { (cm) }\end{array}$ & $\begin{array}{c}\text { Distance } \\
\text { Moved } \\
\text { (m) })\end{array}$ \\
\hline Flav & $09 / 03 / 03$ & 21 & $1-1$ & 7.5 & 0.1 & 0 \\
Flav & $09 / 03 / 03$ & 101 & $1-2$ & 8.2 & 2.0 & 0 \\
Flav & $09 / 03 / 03$ & 101 & $1-2$ & 6.7 & 2.4 & 0 \\
Flav & $09 / 03 / 03$ & 101 & $1-2$ & 7.5 & 1.6 & 0 \\
Flav & $09 / 03 / 03$ & 101 & $1-2$ & 7.7 & 2.2 & 0 \\
Flav & $09 / 24 / 03$ & 80 & $1-2$ & 7.7 & 1.5 & 0 \\
Flav & $09 / 03 / 03$ & 49 & $2-1$ & 9.0 & 1.1 & 48 \\
Flav & $09 / 24 / 03$ & 28 & $2-1$ & 11.0 & 0.1 & 48 \\
Flav & $09 / 03 / 03$ & 92 & $2-2$ & 8.3 & 1.0 & 48 \\
Flav & $09 / 03 / 03$ & 92 & $2-2$ & 8.9 & 1.3 & 48 \\
Flav & $09 / 24 / 03$ & 113 & $2-3$ & 9.3 & 1.3 & 48 \\
Flav & $09 / 03 / 03$ & 55 & $3-1$ & 7.9 & 0.6 & 154 \\
Flav & $09 / 24 / 03$ & 34 & $3-1$ & 10.0 & 0.5 & 154 \\
Flav & $09 / 24 / 03$ & 34 & $3-1$ & 8.6 & 0.6 & 154 \\
Flav & $?$ & $?$ & $3-1$ & $?$ & $?$ & 154 \\
Flav & $09 / 03 / 03$ & 93 & $3-2$ & 8.0 & 1.0 & 154 \\
Flav & $09 / 03 / 03$ & 93 & $3-2$ & 7.5 & 1.1 & 154 \\
Flav & $09 / 03 / 03$ & 93 & $3-2$ & 8.1 & 1.2 & 154 \\
Flav & $09 / 03 / 03$ & 93 & $3-2$ & 7.5 & 0.8 & 154 \\
Flav & $09 / 03 / 03$ & 93 & $3-2$ & 8.2 & 0.3 & 154 \\
Flav & $09 / 03 / 03$ & 135 & $3-3$ & 8.1 & 2.5 & 154 \\
Flav & $09 / 03 / 03$ & 135 & $3-3$ & 7.5 & 1.2 & 154 \\
Plu & $09 / 19 / 03$ & 119 & $3-3$ & 6.4 & 3.0 & 154 \\
Plu & $09 / 19 / 03$ & 119 & $3-3$ & 6.6 & 2.7 & 154 \\
Flav & $09 / 03 / 03$ & 100 & $6-2$ & 7.5 & 0.8 & 133 \\
Plu & $09 / 19 / 03$ & 84 & $6-2$ & 7.0 & 2.0 & 133 \\
Flav & $09 / 24 / 03$ & 79 & $6-2$ & 7.0 & 0.9 & 133 \\
Flav & $09 / 03 / 03$ & 76 & $7-1$ & 7.2 & 2.5 & 216 \\
Flav & $08 / 22 / 03$ & 158 & $8-3$ & 11.6 & & \\
\hline
\end{tabular}


Of the 23 fish migrating from site 1, five moved $48 \mathrm{~m}$ to Site 2, the site closest to the tagging location. To the south, three moved $133 \mathrm{~m}$ to Site 6 , and one moved $141 \mathrm{~m}$ to Site 7. The majority of recaptures were toward the east, where 13 moved $154 \mathrm{~m}$ to Site 3, and one moved $216 \mathrm{~m}$ to Site 8 (Figure 3). The fish recaptured at Site 8 was from the first batch to be tagged and so not only moved the farthest, but also had the longest time at liberty (158 days). Statistically, there were unequal probabilities for the direction taken by migrating fish between the two potential pathways $(p=0.018)$, with a greater chance of finding a tagged fish along the east side of the seaward channel (Sites 3 and 8).

There was no relationship between distance moved and growth rate or days at liberty. Similarly, there was no relationship between distance moved and initial FL, either over all fish or just within those that migrated. However, this test incorporated variability of habitat and school distribution relative to the tagging site, which may obscure the importance of size as a controlling factor in the timing of migration. Half the recaptured migrants moved to School 3. For these 12 fish, the average initial FL of fish was largest for the fish recaptured after the shortest time and smallest for the last fish recaptured (Table 5). The Jonckheere-Terpstra test showed these differences to be statistically significant (test statistic $=8.5 ; p$-value $=0.0126$ ), suggesting that size is an important factor for determining when a fish might migrate.

Table 5. Fork length $(\mathrm{cm})$ for fish recaptured at Site 3 for three different days at liberty (DAL).

\begin{tabular}{cccc}
\hline DAL & $\mathbf{3 4 - 5 5}$ & $\mathbf{9 3}$ & $\mathbf{1 1 9 - 1 3 5}$ \\
\hline & 10.0 & 8.0 & 6.4 \\
& 8.6 & 7.5 & 6.6 \\
& 7.9 & 8.1 & 7.1 \\
Average & & 7.5 & 7.2 \\
Median & 8.8 & 8.2 & 7.1 \\
\hline
\end{tabular}

\subsection{Large-Scale Juvenile/Adult Movement}

To study transitional movements to adult habitats, 1311 fish were tagged (92\% H. flavolineatum, 7\% H. plumierii, 1\% H. scirius; 48 at Corral East, 14 at Coral West, 600 at Romero West, 607 at Caracoles/Majimo). Recapture sampling (Figure 1) consisted of 1110 fish speared, trapped in Antillean arrow traps, or caught in the nets and trap used for tagging. Nineteen fish were recaptured by October 2004 and eight more were recovered by April 2005 (Figure 4, Table 6). All recaptures were H. flavolineatum. Most were caught by spearing, but some were caught during subsequent tagging events. One recovered tag was unreadable because it was a half tag, so individual identification was impossible. From the tagging log and recovery location, it is suspected that this fish was tagged at Romero West. Final recovery for tagged fish is $2.06 \%$ for all methods of recapture.

Of 27 recaptures, 16 showed no displacement $(\leq 50 \mathrm{~m})$ from the tagging location. Thirteen were caught along the original pathway at Romero West 160 days later, while an additional fish was caught 14 days after tagging on a return tagging episode. The other resident fish was recaught at Corral East only 7 days after tagging.

Of the 12 fish that moved, none migrated off the reef of tagging. Time at liberty ranged from 82-503 days. All recaptured fish were recovered in resting schools. Eight of these came from the last round of tagging at Caracoles (March-July 2004). These fish were found less than $0.3 \mathrm{~km}$ from where they were originally tagged. They were in loosely attached schools on the backside of the reef crest, with smaller individuals mixed in. When approached, the fish would disperse individually or in small groups and seek refuge as individuals. Seven fish moved along the submerged reef line and adjacent seagrass beds that constitute the eastern pathway (Figure 4), while one moved along the southwest pathway to the other side of the sand channel. 
Table 6. Recovery data for ontogenetic movement of large-tagged juveniles of Haemulon flavolineatum (Flav) to adult habitat. Days at liberty with stars $\left({ }^{*}\right)$ denote fish recovered at a location other than the tagging location. ? indicates estimates based on a partial tag (see text).

\begin{tabular}{|c|c|c|c|c|c|c|}
\hline Species & Date Tagging & $\begin{array}{l}\text { Days at } \\
\text { Liberty }\end{array}$ & $\begin{array}{l}\text { Tagged } \\
\text { Location }\end{array}$ & $\begin{array}{l}\text { Initial Fork } \\
\text { Length (cm) }\end{array}$ & $\begin{array}{l}\text { Change in Fork } \\
\text { Length }(\mathrm{cm})\end{array}$ & $\begin{array}{c}\text { Distance } \\
\text { Moved (m) }\end{array}$ \\
\hline Flav & $10 / 08 / 2003$ & 7 & Corral East & 10.9 & 0.0 & 0 \\
\hline Flav & $10 / 08 / 2003$ & $503 *$ & Corral East & 9.9 & 4.8 & 109 \\
\hline Flav & $10 / 08 / 2003$ & $503 *$ & Corral East & 10.7 & 3.7 & 109 \\
\hline Flav & $10 / 16 / 2003$ & 292 & Corral East & 11.5 & 2.0 & 0 \\
\hline Flav & $01 / 30 / 2004$ & 160 & Romero West & 11.3 & 0.6 & 50 \\
\hline Flav & $01 / 30 / 2004$ & 160 & Romero West & 11.2 & 0.6 & 50 \\
\hline Flav & $01 / 30 / 2004$ & 160 & Romero West & 10.7 & 0.6 & 50 \\
\hline Flav & $01 / 30 / 2004$ & 160 & Romero West & 12.3 & 1.1 & 50 \\
\hline Flav & $01 / 30 / 2004$ & 160 & Romero West & 10.8 & 0.5 & 50 \\
\hline Flav & $01 / 30 / 2004$ & 160 & Romero West & 10.7 & 0.3 & 50 \\
\hline Flav & $01 / 30 / 2004$ & 160 & Romero West & 12.1 & 0.1 & 50 \\
\hline Flav & $01 / 30 / 2004$ & 160 & Romero West & 10.8 & 0.9 & 50 \\
\hline Flav & $01 / 30 / 2004$ & 160 & Romero West & 11.4 & 0.8 & 50 \\
\hline Flav & $01 / 30 / 2004$ & 160 & Romero West & 12.7 & 0.8 & 50 \\
\hline Flav & $01 / 30 / 2004$ & 160 & Romero West & 11.8 & 1.2 & 50 \\
\hline Flav & $01 / 30 / 2004$ & 160 & Romero West & 10.6 & 0.9 & 50 \\
\hline Flav & $01 / 30 / 2004$ & 160 & Romero West & 11.5 & 1.8 & 50 \\
\hline Flav & $01 / 30 / 2004$ & $390 *$ & Romero West & 11.1 & 3.7 & 109 \\
\hline Flav & $02 / 27 / 2004$ & 14 & Romero West & 11.9 & -0.3 & 50 \\
\hline Flav & $03 / 17 / 2004$ & $97 *$ & Caracoles & 10.8 & 0.4 & 155 \\
\hline Flav & $03 / 17 / 2004$ & $97 *$ & Caracoles & 11.2 & 0.5 & 155 \\
\hline Flav & $06 / 15 / 2004$ & $239 *$ & Caracoles & 10.6 & 3.1 & 153 \\
\hline Flav & $06 / 24 / 2004$ & $82 *$ & Caracoles & 10.5 & 0.6 & 164 \\
\hline Flav & $06 / 30 / 2004$ & $226 *$ & Caracoles & 10.5 & 2.6 & 187 \\
\hline Flav & $07 / 01 / 2004$ & $96 *$ & Caracoles & 11.3 & 0.0 & 297 \\
\hline Flav & $07 / 01 / 2004$ & $223 *$ & Caracoles & 11.5 & 2.1 & 153 \\
\hline Flav & $07 / 01 / 2004$ & 223 * & Caracoles & 10.7 & 2.3 & 153 \\
\hline Flav & $11 / 21-26 / 2003$ & $489-494 ?$ * & Romero West? & $?$ & $2.4-5.7$ & 178 \\
\hline
\end{tabular}

Two fish at Corral East moved around the corner of the reef toward the fore reef and were captured together. Similarly, two fish from Romero West moved to an area at the mouth of the canal on Romero's reef front (depth $-7 \mathrm{~m}$ ). They were loosely aggregated and hidden beneath overhangs and crevices.

Over all recaptures, there was no trend with distance moved and initial FL. For those fish that moved, there was a positive trend of distance moved with initial FL, but the relationship was not statistically significant $(p=0.180)$. The mean initial FL of fish that moved $(11.4 \mathrm{~cm})$ was significantly greater $(p=0.012$, one-tailed test) than that of fish that did not move $(10.8 \mathrm{~cm})$.

\section{Discussion}

Appeldoorn et al. [2,11], Nagelkerken and van der Velde [12], Cocheret de la Morinière et al. [5], and Aguilar-Perera and Appeldoorn [6] demonstrated with length frequency data from Puerto Rico, Columbia, Curacao, and the Bahamas that Haemulon flavolineatum, H. plumierii and H. sciurus move ontogenetically. In this study, forward movement to the reef front was supported by the mark-recapture data. Combined, the two tagging studies showed the collective movement of French grunts (6.4-13.7 cm FL) from the back reef area at Majimo $513 \mathrm{~m}$ to and along the fore reef. The route essentially follows the reef margin, suggesting that the fish were using the reef margin for orientation [18]. However, initial dispersal in the small-scale study occurred primarily along the eastern pathway, indicating that orientation along the reef margin was not the only factor affecting direction. 
The results further indicate that juveniles move by dispersing among the available schools within the general trend toward the reef front. The degree of movement was not affected by individual growth rates, or the days at liberty, but time to dispersal to Site 3 was negatively correlated to FL at tagging. Mean lengths at Site 3 were consistently larger than at the tagging site. These observations and other studies $[15,46,47]$ suggest that the progression of fish through the reef system (individually or in small groups) occurs when fish achieve a size transitional between those characterizing the old and new schools. Five of the six fish recaptured at Site 1 (tagging school) were below the mean size-at-tagging for all recaptured fish, with the sixth only slightly larger than the mean. It is thus possible that these remaining individuals had not yet achieved a size sufficient to transition to another school.

It is not certain how or when small fish move from one school to another. In this study, there was a substantial distance between the various reefs hosting resting schools, so interreef transitions required significant movement over an open habitat. This situation differs markedly from that of McFarland and Hillis [46], where various schools, differing in mean length, were found in close proximity (six schools within a $4 \mathrm{~m}$ diameter collapsed coral head). One likely possibility is that reef transition occurs when fish return after nocturnal feeding. In this study, feeding migration pathways off the reef suggest that fish from Sites 1 , 2 and 3 head for a common feeding area (Figure 3). The extrapolations of observed feeding pathways for each of these sites join in a seagrass area to the north. This provides both an opportunity and means for individual fish from one resting school location to encounter other fish and join their migration back to a new location. Indeed, on several occasions, when monitoring the sunrise migration, it appeared that fish on one migration pathway turned and followed a passing group of fish traveling on a different, intersecting migration pathway. This mechanism may explain why the majority of fish from Site 1 migrated seaward along the eastern margin of the channel. In this sense, migration direction was initially set by factors derived from habitat orientation within the local seascape, which determines the spacing among juvenile resting schools and their orientation to potential off-reef feeding habitats. These initial conditions channeled the majority of migration from Site 1 to being parallel to the coast toward the east, with later movement potentially directed to the offshore reefs of Corral and Turromte, as opposed to the movement to the southeast to the more adjacent offshore reefs of Enrique and Media Luna (Figure 2), as might have been expected based solely on large-scale geomorphology.

McFarland and Hillis [46] suggested that antagonistic behavior among individuals might also be a factor contributing to the transition of fish from one school to another. Antagonistic behavior occurs most commonly during the morning aggregation as fish return to the reef after feeding. As fish come together in small groups, larger juveniles begin mouth pushing, nipping, and chasing. These behaviors increase with the size of the fish. In addition, the largest juveniles may occupy territory on the reef during the day and defend the space through displays and aggressive behavior. Antagonistic behavior may serve to induce individuals to leave the reef in order to reduce the level of antagonism as their length increases. At Site 1, several larger fish at this location were antagonistic and territorial; the largest grunt caught was $12 \mathrm{~cm}$. If these larger fish were indeed resident, they would act to drive others off the reef as they grew. McFarland and Hillis [46] observed one territorial grunt being ejected by a larger, more aggressive individual, in this case forcing the deposed fish to return to a nearby school of medium sized fish.

Grunts have ontogenetic eco-behavioral stages $[2,16,48]$, with sub-adult fish found in loosely knit groups along the reef front. In the large-scale study, recovered fish were less than $15 \mathrm{~cm}$ and recaptured on the same reefs where they were tagged. No recaptures were found further offshore. Although no fish were found off-reef, those fish found to have moved from the tagging location proceeded forward on the reef and entered into loosely knit sub-adult resting schools. This behavior is similar to that observed by Verweij and Nagelkerken [45] when tagging grunts in Southwest Bay, Curacao. They found only three grunts out of 51 recaptures to move significantly, and this movement was into or beyond 
the lagoonal channel to the open reef. Recapture sizes of two found in the channel were 9.8 and $11.1 \mathrm{~cm}$, while the other was found in a later follow-up search fully outside the bay $2 \mathrm{~km}$ from its tagging site with a size of $14.2 \mathrm{~cm}$.

Large-scale movement patterns are hard to generalize, given the limited number of recaptured fish showing movement and the limited movement displayed. However, these data at least suggest that larger juvenile fish move seaward following the distribution of reef habitat as found by Verweij and Nagelkerken [45]. For instance, fish at Corral East moved along reef habitat from the backreef schooling location and around the northeast corner moving forward on the reef. Individuals at Romero West left their juvenile schools and moved into the channel joining schools of sub-adults.

One possible means used for orientation during these movements is vision. It is known that juvenile grunts travel along nightly feeding routes maintained over several months [18] using visual cues [49], and juvenile fish are able to encounter the routes when displaced [50]. Fish at Caracoles followed the reef line to the east and up current, possibly using the nightly feeding migrations as a means of exchange.

Given that the size affected when fish migrated at Majimo and was related to whether larger juveniles moved or not, and that size is an indicator of ontogenetic development and school placement [15], it is reasonable to assume that for large-scale migration to occur, fish must grow to some threshold size. This is supported by Williams [51], who acoustically tagged and transplanted four adult (range 19.0-22.9 FL; average 21.6; SD $1.2 \mathrm{~cm}$ ) and three subadult (range 15.9-18.5 FL; average 17.2; SD $1.3 \mathrm{~cm}$ ) H. plumierii from Turromote to Corral and Romero (Figure 1). Only the adult fish crossed the boundary between these emergent reefs to return to Turromote. This apparent threshold is consistent with the size distribution of $H$. plumieri across the shelf observed by Appeldoorn et al. [2,11].

In the present study, the period of residency and growth for H. flavolineatum is much longer than that reported by other studies. Many authors have reported that in 12 months, haemulids can grow to maturity and a size at which larger migrations can occur [52-55]. To maximize the probability of detecting large-scale movements in the present study, large juveniles (approximately $10 \mathrm{~cm}$ ) were tagged, yet some fish in this study were resident for up to 503 days, and all fish showing movement were recaptured in nearby schools on the same reef where tagged. In that time, the greatest growth interval was under $5 \mathrm{~cm}$ and the greatest size reached was $14.9 \mathrm{~cm}$, similar to Verweij and Nagelkerken's [45] one fish tracked to the open reef. The time-frame for that movement was not reported. It is thus possible that in the present study, the time at liberty was insufficient for growth to the size necessary for large-scale migration. The previous growth studies were based upon otolith readings; however, Brothers and McFarland [1] determined that daily otolith lines were indistinguishable for $H$. flavolineatum after 100 days, and Shaw [55] showed daily lines to grossly underestimate age (and hence overestimate growth) of large juvenile $H$. plumierii over 287 days (aged between 149 to 184 days). From the observed growth among tagged fish [39], however, it is possible that previous growth rates were overestimated, which would explain why off-reef movement was not observed within the duration of this study.

In summary, when making ontogenetic habitat shifts, small juveniles independently move toward the reef front by transiting through schools varying in mean fish length. Movement is not necessarily toward the nearest school, but follows a general pathway. Fish appear to move to new schools primarily by the night-time re-aggregation before returning to the safety of the reef. Short-term movements between schools may be preceded by sparing and antagonistic behavior displays at the home school location and in the feeding grounds. Transfer appears to occur visually during the morning aggregation.

No recaptures of larger juveniles were made off the reefs where tagging occurred, so large-scale movements were not obtained during this study, and the question of ontogenetic group movement to the offshore habitat cannot be answered at this time. Three things contribute to the lack of observed movement off the tagging reef: (i) the time of liberty was of a short duration and perhaps more recoveries could be found with more time; (ii) the effort was small compared to the size of the area searched, and (iii) the number of fish 
tagged was low for a study of this scale, but the lack of manpower and the time available for the study demanded a more manageable number of tagged fish. If a larger-scale migration by $H$. flavolineatum to more offshore adult habitats occurs at $15 \mathrm{~cm}$ FL as suggested by Appeldoorn et al. [11], then 1.5 years at liberty would be needed for grunts to obtain sufficient size for departure when tagged at $10 \mathrm{~cm}$. Rather, grunts appear to be resident upon a reef for about 2 years. Residency and growth rates of recovered fish do not support the premise that grunts mature within 12 months.

Author Contributions: Conceptualization, R.S.A.; methodology, R.S.A. and B.L.K.B.; validation, R.S.A. and B.L.K.B.; formal analysis, R.S.A. and B.L.K.B.; investigation, B.L.K.B.; resources, R.S.A.; data curation, R.S.A.; writing-original draft preparation, B.L.K.B.; writing-review and editing, R.S.A.; visualization, B.L.K.B. and R.S.A.; supervision, R.S.A.; project administration, R.S.A.; funding acquisition, R.S.A. All authors have read and agreed to the published version of the manuscript.

Funding: This research was funded by NOAA/NCCOS through the Coral Reef Ecosystem Studies Program, grant number NA17OP2919. The APC was unfunded.

Institutional Review Board Statement: At the time of this study, there was no ethical review as the University of Puerto Rico at Mayagüez did not have an Institutional Review Board that covered research with wild-caught fishes.

Data Availability Statement: The data presented in this study are available in Tables 2 and 3.

Acknowledgments: R. Hill and C. Recksiek helped perfecting the fish-capture technique, while A. Aguilar, F. Pagan, A. Marshak, K. Cerveny, M. Nemeth, I. Ruiz, and I. Bejarano assisted in the field work. P. Yoshioka and D. Hensley reviewed an earlier draft of this work.

Conflicts of Interest: The authors declare no conflict of interest.

\section{References}

1. Brothers, E.B.; McFarland, W.N. Correlation between otolith microstructure, growth, and life history transitions in newly recruited French grunts [Haemulon flavolineatum (Desmarest), Haemulidae]. Rapp. Procès-Verbaux Réunions Cons. Int. Explor. Mer. 1981, 178, 369-374.

2. Appeldoorn, R.S.; Recksiek, C.W.; Hill, R.L.; Pagan, F.E.; Dennis, G.D. Marine protected areas and reef fish movements: The role of habitat in controlling ontogenetic migration. In Proceedings of the 8th International Coral Reef Symposium; Smithsonian Tropical Research Institute: Panama City, Panama, 1997; Volume 2, pp. 1917-1922.

3. Dahlgren, C.P.; Eggleston, D.B. Ecological process underlying ontogenetic habitat shifts in a coral reef fish. Ecology 2000, 81, 2227-2244. [CrossRef]

4. $\quad$ McBride, R.S.; MacDonald, T.C.; Matheson, R.E., Jr.; Rydene, D.A.; Hood, P.B. Nursery habitats for ladyfish, Elops saurus, along salinity gradients in two Florida estuaries. Fish. Bull. 2001, 99, 443-458.

5. Cocheret de la Moriniere, E.; Pollux, B.J.; Nagelkerken, I.; van der Velde, G. Post-settlement life cycle migration patterns and habitat preference of coral reef fish that use seagrass and mangrove habitats as nurseries. Estuar. Coast. Shelf Sci. 2002, 55, 309-321. [CrossRef]

6. Aguilar-Perera, A.; Appeldoorn, R.S. Variations in juvenile fish density along the mangrove-seagrass-coral reef continuum in SW Puerto Rico. Mar. Ecol. Prog. Ser. 2007, 348, 139-148. [CrossRef]

7. Werner, E.E.; Gilliam, J.F. The ontogenetic niche and species interactions in size-structured populations. Ann. Rev. Ecol. Syst. 1984, 15, 393-423. [CrossRef]

8. Childress, M.J.; Herrnkind, W.F. Influence of conspecifics on the ontogenetic habitat shift of juvenile Caribbean spiny lobsters. Mar. Freshwat. Res. 2002, 52, 1077-1084. [CrossRef]

9. Grol, M.G.G.; Nagelkerken, I.; Rypel, A.L.; Layman, C.A. Simple ecological trade-offs give rise to emergent cross-ecosystem distribution of a coral reef fish. Oecologia 2011, 165, 79-88. [CrossRef]

10. Grol, M.G.G.; Rypel, A.L.; Nagelkerken, I. Growth potential and predation risk drive ontogenetic shifts among nursery habitats in a coral reef fish. Mar. Ecol. Prog. Ser. 2014, 502, 229-244. [CrossRef]

11. Appeldoorn, R.S.; Friedlander, A.; Sladek Nowlis, J.; Ussegilo, P.; Mitchell-Chui, A. Habitat connectivity in reef fish communities and marine reserve design in Old Providence-Santa Catalina, Colombia. Gulf Caribb. Res. 2003, 14, 61-77. [CrossRef]

12. Nagelkerken, I.; van der Velde, G. Connectivity between coastal habitats of two oceanic Caribbean islands as inferred from ontogenetic shifts by coral reef fishes. Gulf Caribb. Res. 2003, 14, 43-59. [CrossRef]

13. Cocheret de la Moriniére, E.; Pollux, B.J.A.; Nagelkerken, I.; van der Velde, G. Diet shifts of Caribbean grunts (Haemulidae) and snappers (Lutjanidae) and the relation with nursery to coral reef migrations. Estuar. Coast. Shelf Sci. 2003, 57, 1079-1089. [CrossRef] 
14. Pereira, P.H.C.; Barros, B.; Zemoi, R.; Ferreira, B. Ontogenetic diet changes and food partitioning of Haemulon spp. coral reef fishes, with a review of the genus diet. Rev. Fish Biol. Fish. 2015, 25, 245-260. [CrossRef]

15. Mateo, J. Función de la Madurez Sexual en el Control de las Migraciones Ontogénicas de la Cachicata Blanca, Haemulon plumieri, (Pices: Haemulidae) en La Parguera, Puerto Rico. Master's Thesis, University of Puerto Rico, Mayagüez, Puerto Rico, 1999.

16. Appeldoorn, R.S.; Aguilar-Perera, A.; Bouwmeester, B.L.K.; Dennis, G.D.; Hill, R.L.; Merten, W.; Recksiek, C.W.; Williams, S.J. Movement of fishes (Grunts: Haemulidae) across the coral reef seascape: A review of scales, patterns and processes. Caribb. J. Sci. 2009, 45, 304-316. [CrossRef]

17. Hill, R.L. Post Settlement Processes and Recruitment Dynamics in the White Grunt, Haemulon plumieri Lacepede (Pices: Haemulidae). Ph.D. Dissertation, University of Puerto Rico, Mayagüez, Puerto Rico, 2001.

18. Ogden, J.C.; Ehrlich, P.R. The behavior of heterotypic resting schools of juvenile grunts (Pomadasyidae). Mar. Biol. 1977, 42, 273-280. [CrossRef]

19. Helfman, G.S.; Meyer, J.L.; McFarland, W.N. The ontogeny of twilight migrations patterns in grunts (Pisces: Haemulidae). Anim. Behav. 1982, 30, 317-326. [CrossRef]

20. Rooker, J.R.; . Dennis, G.D. Diel, lunar and seasonal changes in a mangrove fish assemblage off southwestern Puerto Rico. Bull. Mar. Sci. 1991, 49, 684-698.

21. Burke, N.C. Nocturnal foraging habitats of French and bluestriped grunts, Haemulon flavolineatum and H. Sciurus, at Tobacco Caye, Belize. Env. Biol. Fish. 1995, 42, 365-374. [CrossRef]

22. Nagelkerken, I.; Roberts, C.M.; van der Velde, G.; Dorenbosch, M.; van Riel, M.C.; Cocheret de la Morinière, E.; Nienhuis, P.H. How important are mangroves and seagrass beds for coral-reef fish? The nursery hypothesis tested on an island scale. Mar. Ecol. Prog. Ser. 2002, 244, 299-305. [CrossRef]

23. Beck, M.W.; Heck, K.L., Jr.; Able, K.W.; Childers, D.L.; Eggleston, D.B.; Gillanders, B.M.; Halpern, B.; Hays, C.G.; Hoshino, K.; Minello, T.J.; et al. The identification, conservation, and management of estuarine and marine nurseries for fish and invertebrates. Bioscience 2001, 51, 633-641. [CrossRef]

24. Burke, J.S.; Kenworthy, W.J.; Wood, L.L. Ontogenetic patterns of concentration indicate lagoon nurseries are essential to common grunts stocks in a Puerto Rican bay. Estuar. Coast. Shelf. Sci. 2009, 81, 533-543. [CrossRef]

25. Jaxion-Harm, J.; Saunders, J.; Speight, M.R. Distribution of fish in seagrass, mangroves and coral reefs: Life-stage dependent habitat use in Honduras. Rev. Biol. Trop. 2012, 60, 683-698. [CrossRef] [PubMed]

26. Mateo, I.; Durbin, E.; Appeldoorn, R.S.; Adams, A.J.; Juanes, F.; Kingsley, R.; Swart, P.K.; Durant, D. Assessing the role of mangroves as nurseries for French grunt and schoolmaster through otolith elemental fingerprints. Mar. Ecol. Prog. Ser. 2010, 402, 197-212. [CrossRef]

27. Mumby, P.J. Connectivity of reef fish between mangroves and coral reefs: Algorithms for the design of marine reserves at seascape scales. Biol. Conserv. 2006, 128, 215-222. [CrossRef]

28. Martin, T.; Olds, A.D.; Pitt, K.A.; Johnston, A.B.; Butler, I.R.; Maxwell, P.S.; Connolly, R.M. Effective protection of fish on inshore coral reefs depends on the scale of mangrove-reef connectivity. Mar. Ecol. Prog. Ser. 2015, 527, 157-165. [CrossRef]

29. Dorenbosch, M.; Verberk, W.; Nagelkerken, I.; van der Velde, G. Influence of habitat configuration on connectivity between fish assemblages of Caribbean seagrass beds, mangroves and coral reefs. Mar. Ecol. Prog. Ser. 2007, 334, 103-116. [CrossRef]

30. Munro, J.L. (Ed.) Caribbean Coral Reef Fishery Resources. ICLARM Studies and Reviews 7; International Center for Living Aquatic Resources Management: Manila, Philippines, 1983; 279p.

31. Claro, R.; Lindemen, K.C.; Parenti, L.R. The Ecology of the Marine Fishes of Cuba; Smithsonian Institution Press: Washington, DC, USA, 2001.

32. Meyer, J.; Schultz, E. Migrating haemulid fishes as a source of nutrients and organic matter on coral reefs. Limnol. Oceanogr. 1985, 30, 146-156. [CrossRef]

33. Clark, R.D.; Pittman, S.; Caldow, C.; Christensen, J.; Roque, B.; Appeldoorn, R.S.; Monaco, M.E. Nocturnal fish movement and trophic flow across habitat boundaries in a coral reef ecosystem (SW Puerto Rico). Caribb. J. Sci. 2009, 45, 282-303. [CrossRef]

34. Valdés-Pizzini, M.; Schärer-Umpierre, M. People, Habitats, Species, and Governance: An Assessment of the Social-Ecological System of La Parguera, Puerto Rico; Interdisciplinary Center for Coastal Studies, University of Puerto Rico: Mayagüez, Puerto Rico, 2014.

35. Morelock, J.; Schneidermann, N.; Bryant, W.R. Shelf reefs, southwestern Puerto Rico: Modern and ancient reefs. In Studies in Geology 4. Reefs and Related Carbonates-Ecology and Sedimentology; Frost, S.H., Weiss, M.P., Saunders, J.B., Eds.; American Association Petroleum Geologists: Tulsa, OK, USA, 1977; pp. 17-25.

36. Morelock, J.; Winget, E.A.; Goenaga, C. Geologic Maps of the Southwestern Puerto Rico Parguera to Guánica Insular Shelf. Scale 1:40,000. Map I-2387; Miscellaneous Investigations Series; U.S. Department of the Interior, U.S. Geological Survey: Washington, DC, USA, 1994.

37. Kendall, M.S.; Monaco, M.E.; Buja, K.R.; Christensen, J.D.; Kruer, C.R.; Finkbeiner, M.; Warner, R.A. Methods used to map the benthic habitats of Puerto Rico and the U.S. Virgin Islands. In Benthic Habitats of Puerto Rico and the U.S. Virgin Islands; [CD-ROM]; U.S. National Oceanic and Atmospheric Administration: Washington, DC, USA; National Ocean Service, National Centers for Coastal Ocean Science Biogeography Program: Silver Spring, MD, USA, 2001. Available online: http://biogeo.nos.noaa.gov/ projects/mapping/caribbean/startup.htm (accessed on 12 January 2022).

38. Aguilar-Perera, A.; Appeldoorn, R.S. Spatial distribution of marine fishes along a cross-shelf gradient containing a continuum of mangrove-seagrass-coral reefs off Southwestern Puerto Rico. Estuar. Coast. Shelf Sci. 2008, 76, 378-394. [CrossRef] 
39. Bouwmeester, B.L.K. Ontogenetic Migration and Growth of French Grunt (Teleostei: Haemulon flavolineatum) as Determined by Coded Wire Tags. Master's Thesis, University of Puerto Rico, Mayagüez, Puerto Rico, 2005.

40. Beukers, J.S.; Jones, G.P.; Buckley, R.M. Use of implant micro tags for studies on populations of small reef fish. Mar. Ecol. Prog. Ser. 1995, 125, 61-66. [CrossRef]

41. Buckley, R.M.; West, J.E.; Doty, D.C. Internal micro tag systems for marking juvenile reef fishes. Bull. Mar. Sci. 1994, 55, 848-857.

42. Heidinger, R.C.; Cook, S.B. Use of coded wire tags for marking fingerling fishes. N. Am. J. Fish. Manag. 1988, 8, 268-272. [CrossRef]

43. Anderson, M.; Gorley, R.N.; Clarke, K.R. PERMANOVA+ for PRIMER User Manual; PRIMER-E Ltd.: Plymouth, UK, 2008.

44. R Core Team. R: A Language and Environment for Statistical Computing; R Foundation for Statistical Computing: Vienna, Austria, 2021. Available online: https:/ / www.R-project.org/ (accessed on 12 January 2022).

45. Verweij, M.C.; Nagelkerken, I. Short and long-term movement and site fidelity of juvenile Haemulidae in back-reef habitats of a Caribbean embayment. Hydrobiologia 2007, 592, 257-270. [CrossRef]

46. McFarland, W.N.; Hillis, Z.M. Observations on agnostic behavior between members of juvenile French and white grunts-Family Haemulidae. Bull. Mar. Sci. 1982, 32, 255-268.

47. Huijbers, C.M.; Nagelkerken, I.; Layman, C.A. Fish movement from nursery bays to coral reefs: A matter of size? Hydrobiologia 2015, 750, 89-101. [CrossRef]

48. McFarland, W.N. Observations on recruitment in haemulid fishes. Proc. Gulf Caribb. Fish. Inst. 1980, 32, $132-138$.

49. Quinn, T.P.; Ogden, J.C. Field evidence of compass orientation in migrating juvenile grunts (Haemulidae). J. Exp. Mar. Biol. Ecol. 1984, 81, 181-192. [CrossRef]

50. Hein, R.G. Age, Growth and Factors Controlling Post Settlement Habitat of Juvenile French Grunts (Haemulon flavolineatum) near Tobacco Caye, Belize, Central America. Ph.D. Dissertation, University of Rhode Island, Kingston, RI, USA, 1999.

51. Willliams, S.J. The Movement of White Grunts (Haemulon plumierii) Relative to Habitat and Boundaries at Various Spatial and Temporal Scales. Ph.D. Dissertation, University of Puerto Rico, Mayagüez, Puerto Rico, 2011.

52. Gallardo Cabello, M.; Espino Barr, E.; Gonzalez Orozco, F.; Garcia Boa, A. Age determination of Anisotremus interruptus (Perciformes: Haemulidae) by scale reading, in the coast of Colima, Mexico. Rev. Biol. Trop. 2003, 51, 519-528.

53. Potts, J.C.; Manooch III, C.S. Differences in the age and growth of white grunt (Haemulon plumieri) from North Carolina and South Carolina compared with Southeast Florida. Bull. Mar. Sci. 2001, 68, 1-12.

54. Peters, D.S.; Settle, L.; Burke, J.; Laban, E. Comparative utilization of Florida Bay as a nursery area by juvenile grunts. Bull. Mar. Sci. 1994, 54, 1082.

55. Shaw II, J.C. Otolith Age Validation and Growth of the White Grunt, Haemulon plumieri (Lacipede, 1801) in Southwestern Puerto Rico. Master's Thesis, University of Rhode Island, Kinston, RI, USA, 1997. 